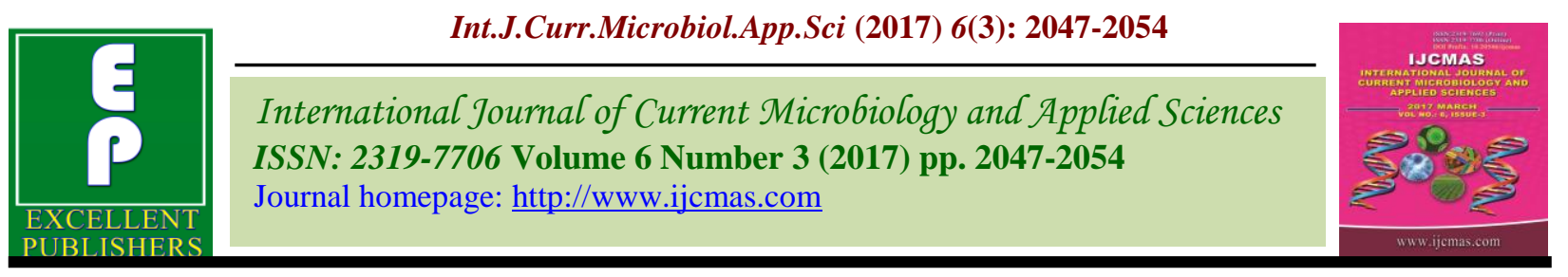

Original Research Article

https://doi.org/10.20546/ijcmas.2017.603.233

\title{
Participatory Empowerment Model for the Sustainability of Dairy Farming
}

\author{
P. Mathialagan ${ }^{1}$, G. Kumaresan ${ }^{2}$ and D. Chandrasekaran ${ }^{3}$ \\ ${ }^{1}$ Registrar, Tamil Nadu Veterinary and Animal Sciences University, Chennai (TN), India \\ ${ }^{2}$ TANUVAS Regional Research Centre, Pudukkottai (TN), India \\ ${ }^{3}$ Department of Animal Nutrition, VCRI, Namakkal (TN), India \\ *Corresponding author
}

A B S T R A C T

\begin{tabular}{|l|}
\hline K e y w o r d s \\
Feeding problems, \\
$\begin{array}{l}\text { Dairy farmers, } \\
\text { Namakkal district, } \\
\text { Empowerment } \\
\text { model. }\end{array}$ \\
\hline Article Info \\
\hline $\begin{array}{l}\text { Accepted: } \\
\text { 20 February } 2017 \\
\text { Available Online: } \\
\text { 10 March } 2017\end{array}$ \\
\hline
\end{tabular}

\section{Introduction}

Dairy animals are fed with concentrates, green fodder and dry fodder by the farmers based on their perceived understanding. Dairy farmers sell the milk to consumer agencies at a non-remunerative price. They also face a lot of problems in the day to day life like low milk yield, low SNF, exploitation by middle men, low sale price, high feed cost, disease outbreaks, infertility etc. It has been found that of the total management cost, 70 per cent is accounted for feeding the dairy animals. Region specific cost effective feeding techniques could help them produce milk at a lucrative price. Based this background, a participatory empowerment model was developed which could be of immense help in making the dairy farming a profitable venture.

\section{Materials and Methods}

Namakkal district was selected for the purpose of developing the participatory empowerment model for dairy farmers due to predominant cattle and buffalo population and milk shed area. The farmers of this area are depending on dairying and animal husbandry for their livelihood. This project was implemented from the financial assistance of Department of Science and Technology, Government of India.

Namakkal district has 12 blocks. Ten (10) blocks were selected for implementation of the project. From each block one village was selected. The village selection in each block was made based on cattle population and effective functioning of the milk producers' 
co-operative society. Women dairy farmer SHGs was formed in every selected village.

The model has the following components as shown in the figure 1 .

\section{Dissatisfaction of dairy farmers}

The dairy farmers were dissatisfied due to variety of socio-economic and technological factors. This was learnt during various types of interactions with the dairy farmers, during office calls, farm and home visits, campaigns and during the visit of students to villages for practical classes.

The dissatisfaction was expressed in terms of low milk yield, low SNF in milk, low sale price, exploitation by middlemen, high feed cost, disease outbreaks, infertility etc. Hence dissemination of a proven model for dairy farming will be a boon to dairy farmers. It has been shown as the causes for developing a model with the title "Disenchantment for dairy farming".

\section{Empowerment process}

\section{Situation, problem and cause analyses}

The deployment of participatory resource appraisal techniques in the project villages helped to locate resources like veterinary hospitals, marketing facilities, and identifying problems like lack of knowledge on balanced feeding and on increasing milk solids not fat (SNF), infertility management, diseases and the reasons for the same were the causes for disenchantment of dairy farming.

\section{Farm resource and feeding pattern analysis}

An interview schedule was prepared and farm resource appraisal was carried out at each and every farm of the selected respondents and feeding pattern was analyzed at every dairy animal level. Individual animal's breed, age, milk yield, fat and SNF per cent, length and girth measurements for calculating body weight and quantity of feed ingredients fed were collected.

\section{Development of interventions Integrated micro level approach)}

\section{(ICT}

Based on the situation, problem and cause analysis and resources appraisal, a software was developed to find out the adequacy and inadequacy of the feed given by the farmer to dairy animal. The data were computerized and the nutritional requirement of that individual animal and the requirement met by their current feeding pattern were worked out.

\section{Capacity building}

Out of the 10 SHGs, 159 beneficiaries rearing lactating cows and buffaloes alone were selected and subjected to this study. They were marketing the milk through dairy cooperatives and private milk vendors. The price of milk was mainly based on the fat and SNF content. Hence to improve the quality of milk and to exploit the full potential of a dairy animal, appropriate feeding practices should be followed so as to meet out the nutritional requirement of the animal.

Multi-disciplinary team has conducted on farm and institutional training programme for the beneficiaries. Initially the importance of balanced feeding to dairy animals was insisted in the training programme. Necessary demonstrations and field trips were conducted to impart knowledge and skills on feeding of animals and entrepreneurial skills.

The components of field demonstration consisted of

1. Fodder cutting \& feeding techniques to increase SNF content milk

2. Cleaning of dairy cattle

3. Disinfection and sanitation of shed 
4. Milking methods

5. Cleaning of udder

6. Wiping of udder

\section{Input supply}

Following critical inputs were distributed to the adopted farmers at free of cost to motivate them and thereby to adopt the recommended technologies.

1. Stipend for attending training programme.

2. Trace minerals $-5 \mathrm{gm} / \mathrm{day} / \mathrm{animal}$

3. Calcite powder $-50 \mathrm{gm} / \mathrm{day}$

4. Soda bicarbonate $-10 \mathrm{gm} / \mathrm{day}$

5. Sodium chloride $-50 \mathrm{gm} /$ day/animal

6. Extension literature on the transferred technologies.

Trace minerals and calcite were supplied to increase the quality and quantity of milk of trial dairy animals.

\section{ICT integrated micro level approach (Feed prescription/animal)}

A low cost balanced ration to the individual animals with the available resource based feed ingredients was formulated and "a low cost, balanced, feed prescription" was issued to the dairy animals of the beneficiaries.

\section{Husbandry and clinical counseling}

The project team had continuously made follow-up visits to the selected villages to provide suitable technical advices to farmers. Difficulties identified in adoption were suitably rectified. Milk samples were collected before and after the feeding intervention and tested for fat and SNF content.

\section{Entrepreneurship development}

Linkages for finance and insurance facilities were extended to the motivated farmers. Marketing opportunities were created by establishing linkages with co-operative societies and preference to direct marketing of milk was given.

\section{Result demonstration meetings}

Result demonstration meetings were conducted in all the 10 villages with the participation of local leaders, officials from various development departments and farmers. The beneficiaries shared their experience on what they gained from the project and the impact created by the scheme with the non-participants in the selected villages.

\section{Dissemination of results by mass media}

The results were broadcast, telecast and published through popular magazine for wider adoption.

\section{Results/outcome of the project}

The implementation of the model through, capacity building, resulted in an increase in knowledge to the extent of 59.43 per cent, and skill developed led to technology adoption.

Table 1 reveals that more than half of the beneficiaries $(59 \%)$ were feeding concentrate feed from off-farm resources.

Majority of the beneficiaries (63.25\%) were feeding in excess of the nutritional requirement of their dairy animal. The reason for over feeding could be free availability the agricultural by products from their own farm.

Over one tenth $(13.68 \%)$ of the beneficiaries were found to feed their animals with unbalanced feed with deficiency in more than one component. About one fifth $(22.22 \%)$ of the farmers were in the group of overfeeding with deficiency in dry matter intake (DMI), $\mathrm{Ca}, \mathrm{P}$ or $\mathrm{CP}$.

Among these, calcium deficiency alone has 
been observed in 11.11 per cent of the cases that is evident from the incidence of milk fever problems faced by these farmers. Phosphorus deficiency has been recorded in 5.13 per cent cases, which could be mainly due to lack of feeding of rice bran to the dairy animals.

Crude protein deficiency has also been recorded in 3.42 per cent cases due to negligence of incorporating oil cake and dry fodder in their feed.

A small proportion of farmers $(2.56 \%)$ was found to feed their animals with deficiency in dry matter intake which could be due to feeding more concentrate and less roughage meeting the nutrition need but not the dry matter need. A negligible 0.85 per cent has been found to feed their animals with nutritionally deficient feed.

Table.1 Analysis of feeding pattern followed by the beneficiaries

\begin{tabular}{|c|c|c|}
\hline S.No. & Feeding pattern & $\begin{array}{c}\text { Per cent of } \\
\text { respondents }\end{array}$ \\
\hline 1. & Feeding concentrate & 59.83 \\
\hline 2. & Overfeeding & 63.25 \\
\hline 3. & Overfeeding with calcium deficiency & 11.11 \\
\hline 4. & Overfeeding with P deficiency & 5.13 \\
\hline 5. & Overfeeding with CP deficiency & 13.68 \\
\hline 6. & Overfeeding with DMI deficiency & 2.56 \\
\hline 7. & Unbalanced overfeeding with deficiency in & 13.68 \\
\hline 8. & more than one component & 0.85 \\
\hline
\end{tabular}

Table.2 Effect of the model on quality and quantity of milk production

\begin{tabular}{|c|c|c|c|}
\hline \multirow{2}{*}{$\begin{array}{c}\text { Sl. } \\
\text { No. }\end{array}$} & Nature of Effect & Cow & Bype of Animal \\
\cline { 3 - 4 } & & 0.49 & 0.35 \\
\hline 1 & Increase in SNF contentment of milk (\%) & 1.12 & 0.8 \\
\hline 2 & Increase in milk yield per day /animal (liter) & 1 to 0.2 & 5 to Nil \\
\hline 3 & Reduction in the incidence of milk fever (\%) & 28.77 & 27.21 \\
\hline 4 & Reduction in cost of production of milk (\%) & & \\
\hline
\end{tabular}


Table.3 Effect of the model on the period of conception after calving in dairy cattle

\begin{tabular}{|l|l|c|c|}
\hline Sl. No. & \multicolumn{1}{|c|}{ Indicator } & \multicolumn{2}{|c|}{ Animal Category } \\
\cline { 3 - 4 } & & Cow & Buffalo \\
\hline 1. & Before adoption & 6 months to 1 year & 1 to 1.5 years \\
2. & After adoption & 45 days to 3 months & 2 to 4 months \\
\hline
\end{tabular}

Table.4 Financial support for the dairy farming

\begin{tabular}{|c|c|c|}
\hline S. No. & Entrepreneurship development & Per cent \\
\hline 1. & Availed bank credit & 74 \\
\hline 2. & Followed various marketing strategies & 71 \\
\hline 3. & Started direct selling of milk & 25 \\
\hline 4. & Learnt record keeping/accounting/ bank transaction & 80 \\
\hline 5. & Started new ventures & 60 \\
\hline 6. & Expanded the existing livestock enterprise & 40 \\
\hline
\end{tabular}

Table.5 Comparison of the results of participatory empowerment model for dairy farmers with the existing technology transfer model

\begin{tabular}{|c|l|l|l|l|l|}
\hline S. No. & Parameter studied & \multicolumn{2}{l|}{ Cow milk } & \multicolumn{2}{l|}{ Buffalo milk } \\
\cline { 3 - 6 } & & $\begin{array}{l}\text { Existing } \\
\text { model }\end{array}$ & New model & $\begin{array}{l}\text { Existing } \\
\text { model }\end{array}$ & New model \\
\hline 1 & $\begin{array}{c}\text { Increase in SNF contentment } \\
\text { of milk (\%) }\end{array}$ & $8.02 \pm 0.21$ & $8.51 \pm 0.19$ & $8.63 \pm 0.21$ & $8.98 \pm .016$ \\
\hline 2 & $\begin{array}{c}\text { Increase in milk yield per } \\
\text { day /animal (litter) }\end{array}$ & $7.43 \pm 0.20$ & $8.55 \pm .0 .21$ & $7.26 \pm 0.21$ & $8.06 \pm 0.14$ \\
\hline 3 & $\begin{array}{c}\text { Reduction in the incidence of } \\
\text { milk fever (\%) }\end{array}$ & $1.02 \pm 0.01$ & $0.20 \pm 0.001$ & $5.01 \pm 0.01$ & 0.00 \\
\hline 4 & $\begin{array}{c}\text { Reduction in cost of } \\
\text { production of milk (Rs) }\end{array}$ & $36.14 \pm 0.54$ & $25.74 \pm 0.50$ & $31.25 \pm 0.54$ & $22.74 \pm 0.49$ \\
\hline
\end{tabular}


Figure.1 Dairy Farmers Participatory Empowerment Model (DFPEM)

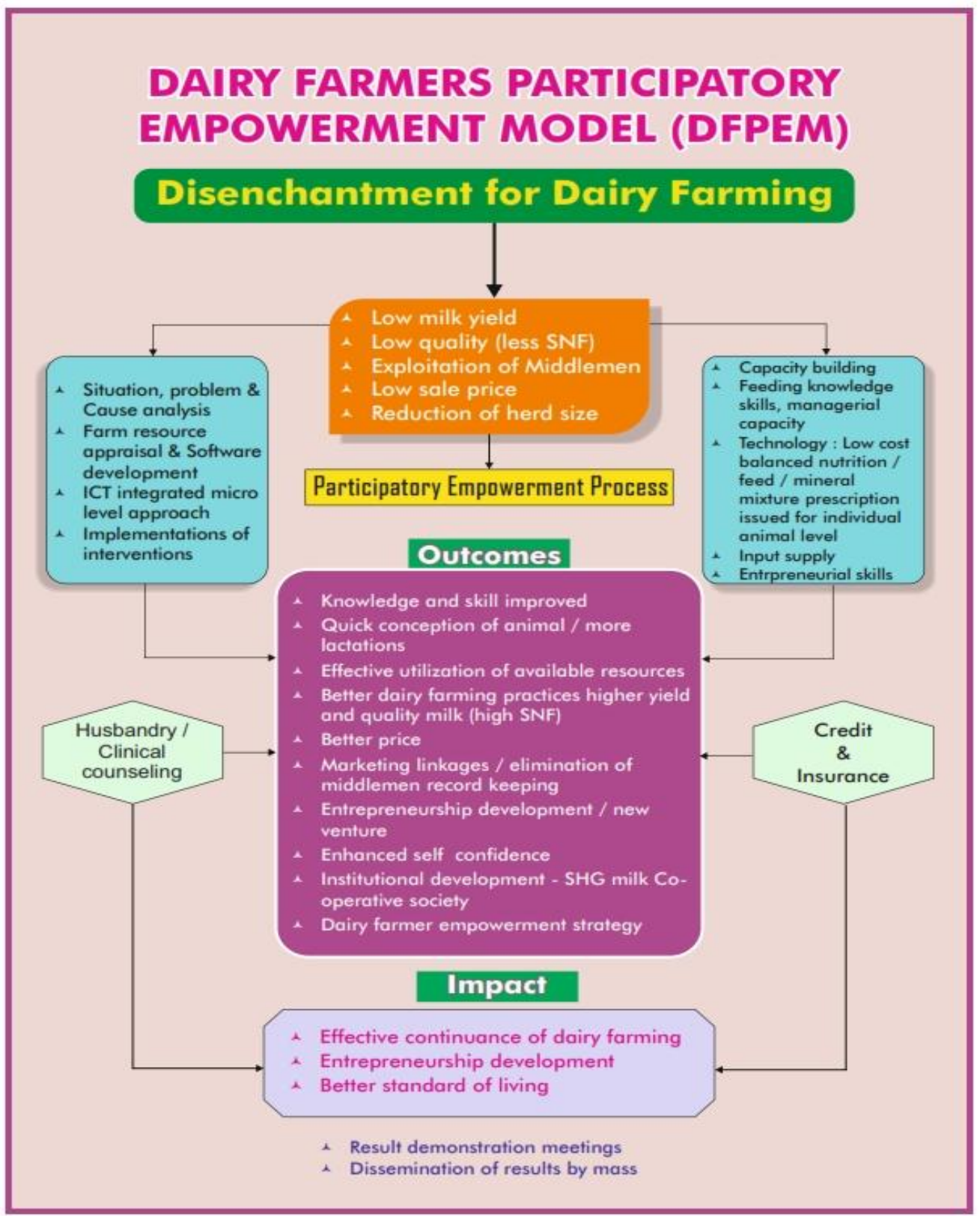

The results revealed that there was an average of 0.49 per cent and 0.35 per cent increase in SNF content of milk in cows and buffaloes, respectively after supplementing the diet with trace minerals and calcite. This has led to an average increase in milk production in cows about 1.12 litre and in buffaloes 0.8 litre per day per animal (Kumaresan et al., 2008).
It has been observed that 46.37 per cent of cow milk samples had less than 8.0 per cent of SNF content (Kumaresan et al., 2008). The payment for the milk is usually calculated based on the fat content of the milk as per the price policy of milk co-operative societies if the SNF content is less than 8.0 per cent. In such cases, the farmer would get only a less price. 
There was reduction in the incidence of milk fever cases from 1 per cent to 0.2 per cent in case of cows and 5 per cent to nil cases in buffaloes (Kronqvist et al., 2012). On the overall 28.77 per cent and 27.21 per cent of cost reduction has been worked out for cows and buffaloes through the scheme respectively (Thanh and Suksombat, 2015).

After calving, cows used to get conceived within six months to one year period earlier. But after adoption of the various technologies through the scheme, it was reported that after calving, the cows could conceive between 45 days to 3 months post calving. In buffaloes also, the conception period after calving was improved from 1-1.5 years to 2-4 months after adoption of technologies.

Table 4 shows that majority $(74 \%)$ of the beneficiaries reported that they were able to make arrangements / get bank loan from various financial institutions.

Nearly three-fourths $(71 \%)$ of them opined that they followed the various marketing strategies as learned / taught through the training programmes. Some of them have started direct selling of milk after participation in the scheme.

Majority (80\%) also observed that they became aware about the record keeping /accounting / bank transaction procedures and presents the accounts for auditing. About 60 per cent of the beneficiaries stated that they could involve in starting of new ventures like promoting and selling of mineral mixture to other dairy farmers of the village.

Two-fifths (40\%) of them expressed that they could expand their existing livestock enterprise with more number of animals / birds to start new enterprise like commercial poultry farming, mini dairy etc. After participation in the scheme, the beneficiaries started fixing the price by themselves based on the age and production performance of the animal. Earlier the middlemen used to exploit their ignorance on selling of the animals products / animals and fix less price for the animals / products. In some of the villages other farmers who sold their milk to private vendors earlier, expressed willingness to join the milk co-operatives, because of the higher sale price given to the milk of the scheme beneficiaries. In the villages where milk cooperatives are not functioning, the scheme beneficiaries have taken initiative to start new milk co-operative societies. The officials of the milk co-operative societies have been contacted and administrative procedures have been intimated to the beneficiaries for starting new society.

Some of the beneficiaries used to directly contact other farmers and collect /sell milk after entrepreneurship training and their husbands sell the milk in the nearby town area.

The table 4 highlights the comparison of the results of participatory empowerment model for dairy farmers with the existing technology transfer model. In the existing dairy farmers technology transfer model, feeding technology is generalized and the approach is at macro level. Whereas in the new model the dairy cattle feeding is based on a) the availability of individual farmer's farm resources, b) individual animals' body weight, c) individual animals' production potential, d)farmer participatory, e) ICT integrated and micro level approach. This new model, identified the gap in the feeding pattern and prescribed a suitable least cost module to fill up the gap.

The dairy farmer's participatory empowerment model increased the SNF contentment of milk and also increased the milk yield per day. It also reduced the incidence of milk fever and cost of production of milk. 


\section{Impact}

Continued adoption of dairy farming resulted, in large scale entrepreneurship development. This led to emerging of various institutions which resulted in profitability and sustainability of dairy enterprise with successful forward and backward linkages. Thus this model ultimately depicted the significant improvement in the standard of living of the dairy farmers.

In conclusion dissatisfaction of dairy farmers of Namakkal district of Tamil Nadu led to the idea of developing a participatory, ICT integrated, micro level approach dairy farmer's empowerment model. This model includes the steps such as situation, problem and cause analyses, farm resource appraisal, development of interventions (Soft ware development), ICT integrated micro level approach (Low cost feed prescription), Capacity building, Input supply, Husbandry and Clinical counseling, Entrepreneurship development, Result demonstration meetings and Dissemination of results by mass media.

The outcome of the project resulted in economic, social, psychological and technological empowerment of dairy women. Good impact was observed after successful adoption of this model. Overall this programme resulted in quick conception of animals, leading to increment in quality and quantity of milk production, efficient resource utilization and better dairy farming practices. This had a good impact on the price of milk, marketing, proper record keeping, development of self confidence, starting new ventures, better functioning of the existing milk societies. This model could be successfully translated to other dairy belts in India to ensure sustainable dairy venture of farm women.

\section{References}

Kronqvist, C., Emanuelson, U., Tråvén, M., Spörndly, R., Holtenius, K. 2012. Relationship between incidence of milk fever and feeding of minerals during the last 3 weeks of gestation. Animal. 6:1316-21

Kumaresan, G, Saravanakumar, K., Murugan, B., Rajendran,D., Devendran, P., and Annal Villi, R. (2008) Finely ground dry corn supplementation to improve solids not fat content of crossbred cattle milk during summer under tropical climate. J. Applied Sciences Research 4: 202-206.

Thanh, L.L., Suksombat, W. 2015. Milk production and income over feed costs in dairy cows fed medium-roasted soybean meal and corn dried distiller's grains with soluble. Asian-Australas J Anim Sci., 28: 519-529.

Yu, P., Huber, J.T., Santos, F.A.P., Simas, J.M., and Theurer, C.B 1998. Effects of ground, steam flaked and steam rolled corn grains on the performance of lactating cows. J Dairy Sci. 81:777783

\section{How to cite this article:}

Mathialagan, P., G. Kumaresan and Chandrasekaran, D. 2017. Participatory Empowerment Model for the Sustainability of Dairy Farming. Int.J.Curr.Microbiol.App.Sci. 6(3): 2047-2054. doi: https://doi.org/10.20546/ijcmas.2017.603.233 